\title{
Effect of high voltage pulsed galvanic stimulation on sacral transcutaneous oxygen tension levels in the spinal cord injured
}

\author{
A R Mawson DrPH, ${ }^{1,2 *}$ F H Siddiqui MB BCh, ${ }^{3}$ B J Connolly BS, ${ }^{4}$ C J Sharp BS, \\ G W Stewart MD ${ }^{5}$ W R Summer MD,${ }^{6} \mathrm{~J}$ J Biundo Jr MD ${ }^{7,8}$ \\ ${ }^{1}$ President, Chalfont Corporation, New Orleans, Louisiana; ${ }^{2}$ formerly Assistant Professor, \\ Department of Medicine, ${ }^{3}$ Visiting Instructor, Section of Physical Medicine and \\ Rehabilitation, ${ }^{4}$ Medical Student, ${ }^{5}$ Assistant Professor, Section of Physical Medicine \\ Rehabilitation, ${ }^{6}$ Professor and Chief, Section of Pulmonary and Critical Care Medicine, \\ ${ }^{7}$ Professor and Chief, Section of Physical Medicine and Rehabilitation, Louisiana State \\ University Medical Centre, New Orleans, Louisiana 70112; ${ }^{8}$ Director, Louisiana \\ Rehabilitation Institute, Charity Hospital, New Orleans, Louisiana, USA.
}

\begin{abstract}
Evidence is mounting that spinal cord injured (SCI) persons may be at increased risk of pressure ulcers due to prolonged immobilization together with the injury-induced loss of sympathetic tone and decreased vascular resistance. With a view to developing a new method of preventing pressure ulcers, the objective of this study was to determine whether high voltage pulsed galvanic stimulation (HVPGS) could increase sacral transcutaneous oxygen tension $\left(\mathrm{P}_{\mathrm{tc}} \mathrm{O}_{2}\right)$ in SCI persons lying prone and supine. In experiment 1, HVPGS applied to the back at spinal level T6 led to a sustained, dose-related increase in sacral $\mathrm{P}_{\mathrm{tc}} \mathrm{O}_{2}$ in 3 subjects lying prone. In experiment 2, carried out on 29 subjects lying supine on egg-crate mattresses, HVPGS $(75$ volts, $10 \mathrm{~Hz})$ produced a $35 \%$ increase in sacral $\mathrm{P}_{\mathrm{tc}} \mathrm{O}_{2}$, from a baseline level (Mean $\pm \mathrm{SD}$ ) of $49 \pm 21 \mathrm{mmHg}$ to $66 \pm 18 \mathrm{mmHg}$ after 30 minutes of stimulation $(F=39.4, p<.00001)$. In experiment 3, simulated HVPGS was found to have no effect on sacral $\mathrm{P}_{\mathrm{tc}} \mathrm{O}_{2}$ in 5 subjects lying supine. In experiment 4, HVPGS was repeated on 10 subjects and its effects found to be highly reproducible. It is hypothesized that HVPGS restores sympathetic tone and vascular resistance below the level of the spinal cord lesion, thereby increasing the perfusion pressure gradient in the capillary beds. Randomized controlled trials are now indicated to determine the efficacy of HVPGS for preventing pressure ulcers.
\end{abstract}

Keywords: pressure ulcers; electrical stimulation-pulsed galvanic; oxygen tissue levels.

\section{Introduction}

Pressure ulcers occur in $28-85 \%$ of spinal cord injured (SCI) patients, often within a few days of injury, and tend to develop on the lower parts of the body, especially the sacrum, trochanters, and ischial tuberosities. ${ }^{1-5}$ Prolonged external pressure, resulting in impaired capillary circulation, is considered the major causal factor and frequent repositioning the key to preven-

*Correspondence: 1831 Bordeaux Street, New Orleans, LA 70115, USA. tion. ${ }^{6-9}$ Although localized pressure may be a necessary factor, it is not sufficient to explain the unusual susceptibility of SCI persons to pressure ulcers. Intrinsic as well as extrinsic factors determine the formation of pressure ulcers. ${ }^{10}$

The most important intrinsic factor is thought to be reduced sympathetic tone in the vascular bed below the level of the lesion, due to the interruption of spinal vasomotor pathways. ${ }^{10}$ This defect in vascular control may interact synergistically with ischemia due to external pressure to increase the risk of cellular damage and 
necrosis. The reduced blood supply of SCI patients below the level of injury ${ }^{11}$ may further compromise the tissue supply of $\mathrm{O}_{2}$ and other components carried by circulating blood. ${ }^{12}$ Consistent with other data supporting this emerging view, ${ }^{13,14}$ we have found that SCI persons have significantly lower transcutaneous oxygen tension $\left(\mathrm{P}_{\mathrm{tc}} \mathrm{O}_{2}\right)$ levels at the sacrum compared to able bodied controls, especially when lying supine; furthermore, SCI persons below the median supine $\mathrm{P}_{t c} \mathrm{O}_{c}$ value were significantly more likely to have a pressure ulcer than those above the median, suggesting that $\mathrm{P}_{\mathrm{tc}} \mathrm{O}_{2}$ may be a useful indicator of susceptibility to pressure ulcers. ${ }^{15}$ Bogie et al ${ }^{16}$ recently reported that spinal cord injured persons who were walking at discharge had significantly higher sacral $\mathrm{P}_{\mathrm{tc}} \mathrm{O}_{2}$ levels during their hospitalization than wheelchair dependent subjects. In an earlier prospective study on the development of pressure ulcers in SCI persons, ${ }^{4}$ we found a significant association between systolic blood pressure at the time of admission to the hospital and the development of ulcers. The partial pressure of oxygen $\left(\mathrm{PaO}_{2}\right)$ was also lower in SCI patients who developed ulcers. These findings of significantly reduced blood pressure and slightly lower $\mathrm{PaO}_{2}$ likewise suggest an increased susceptibility of the tissues to hypoperfusion and oxygen delivery, with resultant pressure ulcers.

Based on the above review of etiologic factors, pressure ulcers might be prevented, in theory, by increasing the patient's resistance to pressure. Prevention efforts have mainly focused on ways of reducing external pressure through repositioning and the use of pressure-relieving devices. ${ }^{17-19}$ However, such efforts are only partially effective at best. Acute SCI patients often cannot be repositioned due to spinal or vasomotor instability, thereby virtually guaranteeing a pressure ulcer; moreover, the nursing staff are usually insufficient to turn all patients at risk with sufficient frequency. Pressurerelieving mattresses and beds also tend to be expensive and few have been evaluated for efficacy. ${ }^{20,21}$ In view of these limitations, it would be desirable to find a way of increasing the SCI person's resistance to pressure ulcers.
Review of the literature suggests that electrical stimulation can increase cutaneous blood flow in the spinal cord injured ${ }^{11,22-25}$ and promotes wound healing in general and the healing of pressure ulcers in particular. 23,26-33 Several reports indicate that high-voltage, pulsed galvanic stimulation (HVPGS) increases the healing rate of skin wounds. ${ }^{29,34-38}$ However, the conditions required for maximum effectiveness of HVPGS in treating soft tissue injuries are uncertain. Bourguignon and Bourguignon ${ }^{39}$ examined the effect of HVPGS on protein and DNA synthesis in cell culture. Fibroblast cells were exposed to HVPGS of various voltages and pulse rates for 20 minutes. Maximum stimulation of proteins and DNA synthesis was obtained at 50 volts and 75 volts, respectively, with a pulse rate of 100 pulses/s and the cells located near the negative electrode. Exposure to HVPGS intensities greater than 250 volts was inhibitory for both protein and DNA synthesis. Because fibroblasts are involved in all types of soft tissue healing, it was felt that the results obtained were relevant to the treatment of patients. Levine et al ${ }^{25}$ compared blood flow in the gluteus maximus muscle in 8 able bodied and $6 \mathrm{SCI}$ subjects in response to electrical stimulation $(50 \mathrm{~Hz}$, with a duty cycle of $2 \mathrm{~s}$ on, $4 \mathrm{~s}$ off). Blood flow was measured under the ischial tuberosities, using xenon 133 clearance, while the subjects were seated. All subjects showed an increase in blood flow during stimulation, the increase being greater $(p<0.05)$ for the able bodied than for the SCI group $(p=0.12)$. Overall, studies to date suggest that electrical stimulation may reverse or arrest the processes responsible for pressure ulcer development.

We hypothesize that electrical stimulation may help to prevent pressure ulcers by restoring sympathetic tone below the level of the lesion, thereby increasing the perfusion pressure gradient in the capillary beds and enhancing tissue oxygenation. The objectives of this study were to determine the effect of HVPGS on sacral transcutaneous oxygen tension $\left(\mathrm{P}_{\mathrm{tc}} \mathrm{O}_{2}\right)$ levels in SCI subjects lying (a) prone (experiment 1) and (b) supine (experiment 2); to determine the effect on $\mathrm{P}_{\mathrm{tc}} \mathrm{O}_{2}$ levels of simulated HVPGS 
(experiment 3); and to determine the reproducibility of HVPGS (experiment 4).

\section{Experimental methods and design}

\section{Subjects}

The SCI subjects taking part in this study were volunteers, ages 18 years and older, recruited from inpatients of the Louisiana Rehabilitation Institute. Written informed consent was obtained from all participants and the study protocol was approved by Louisiana State University Medical Center's Institutional Review Board. All SCI subjects who were asked to participate agreed to do so.

\section{Definitions and measures}

The diagnosis of SCI and the level of lesion were accepted as recorded by the attending physician in the patients' hospital charts. Subjects were classified diagnostically as either paraplegic (complete or incomplete) or quadriplegic (complete or incomplete).

Tissue oxygenation at the sacrum was measured using a transcutaneous oxygen tension $\left(\mathrm{P}_{\mathrm{tc}} \mathrm{O}_{2}\right)$ monitor (Model 811, Novametrix Medical Systems, Wallingford, CT). The sacrum was selected for $\mathrm{P}_{\mathrm{tc}} \mathrm{O}_{2}$ monitoring since it is the site at greatest risk of pressure ulcer development. The $\mathrm{P}_{\mathrm{tc}} \mathrm{O}_{2}$ monitor incorporates a modified Clark polarographic electrode. Oxygen tension is measured through the use of an incorporated heating system which maintains the temperature of the electrode and the site beneath it at a set point $\left(44.5^{\circ} \mathrm{C}\right)$. Heating the site beneath the electrode facilitates the diffusion of oxygen from the underlying tissue to the skin surface. $\mathrm{P}_{\mathrm{tc}} \mathrm{O}_{2}$ was studied because it can be measured continuously and noninvasively, and because at $44.5^{\circ} \mathrm{C}$, in infants, it reportedly indicates the state of oxygen supply and demand in the cutaneous and subcutaneous tissues. ${ }^{40}$ In normal infants and adults, $\mathrm{P}_{\mathrm{tc}} \mathrm{O}_{2}$ correlates highly with arterial oxygen values. ${ }^{+1 .+2} \mathrm{P}_{\mathrm{tc}} \mathrm{O}_{2}$ values are reliable, continuous, noninvasive trend monitors of $\mathrm{PaO}_{2}$ in critically ill subjects. During circulatory problems, when $\mathrm{P}_{\mathrm{tc}} \mathrm{O}_{2}$ values are compared to $\mathrm{PaO}_{2}$ values. changes in $\mathrm{P}_{\mathrm{tc}} \mathrm{O}_{2}$ reflect trends in the severity of flow shock. ${ }^{43}$ In local areas of reduced blood flow due to imposed pressure, $\mathrm{P}_{\mathrm{tc}} \mathrm{O}_{2}$ is assumed to reflect changes in oxygen delivery and demand.

A high voltage pulsed galvanic stimulator (Model GVII, Medical Devices, St Paul, $\mathrm{MN}$ ), was used for electrical stimulation. High voltage pulsed galvanic stimulation (HVPGS) is characterized by a twin-peak monophasic wave form with a fixed duration in the microsecond range (up to $200 \mu \mathrm{s}$ ) and a voltage normally above 100 volts. ${ }^{44} \mathrm{By}$ using a decreased pulse duration and an increased voltage, deeper tissues can be stimulated without producing tissue damage. The waveform is a monopolar twin peak with an instantaneous rate of rise and a slope on the downside of each peak. The intrapulse interval is permanently fixed at $100 \mu \mathrm{s}$. The pulse duration is measured at one-half of the pulse height (ie $5 \mu \mathrm{s}$ ) and likewise cannot be modified by the operator. The frequency is adjustable with a range of 1-100 pulse pairs/second $(\mathrm{Hz})$. The intensity of the output voltage is adjustible with a range of $0-350$ volts. The amount of current is restricted to microamperes, with a range of $0-700 \mu \mathrm{A}$ and a maximum charge per pulse of 3.5 microcoulombs ( 7 microcoulombs/pair).

Skin offers considerable resistance (as high as 100,000 ohms) to the flow of electrical current. When a current of low voltage units (ie TENS) is passed through a circuit containing resistors, drops in voltage occur and energy is lost. A high-voltage device produces a spontaneous breakdown in skin resistance. Procacci et al ${ }^{45}$ noted that when a high voltage stimulus (100 volts) was passed through a circuit designed to mimic the skin's electrical circuit, the current tended to flow toward the path of the capacitor. Since little energy is wasted crossing a capacitor, as compared to crossing a resistor, a greater amount of current density occurs beneath the skin and reaches the target tissues; in addition, since a minimal amount of high-voltage current passes across the resistor side of the circuit, less energy is lost and converted to heat. ${ }^{32}$

What degree of skin irritation, if any, can be expected after prolonged treatment with 
HVPGS? In one study using HVPGS for 30 minutes at an intensity of 100 volts and a frequency of $80-82 \mathrm{~Hz}$, no significant change in skin $\mathrm{pH}$ was found. ${ }^{44}$ Since the pulse duration of HVPGS ranges up to $200 \mu \mathrm{s}$, the probability of stimulating the A-delta (pain and temperature) and $\mathrm{C}$ (pain) sensory axons is decreased, thus minimizing the subject's discomfort. ${ }^{32}$

\section{Data collection}

The study was carried out on SCI subjects lying on egg-crate mattresses. The $\mathrm{P}_{\mathrm{tc}} \mathrm{O}_{2}$ sensor was first calibrated in room air and a drop of contact gel free of air bubbles was applied to the oxygen sensor membrane. With the subject lying prone, the areas for sensor placement and stimulation were thoroughly cleaned with alcohol. The sensor was applied to the skin at approximately the second sacral segment along the midline using a two-sided adhesive ring, thereby ensuring an airtight seal. Two electrodes and conductive sponges, measuring $4 \mathrm{~cm}$ in diameter, were used for administering electrical stimulation.

Experiment 1 was carried out to determine whether HVPGS could increase sacral $\mathrm{P}_{\mathrm{tc}} \mathrm{O}_{2}$ in subjects lying prone. Three subjects participated in this experiment; 2 were incomplete quadriplegics, one a complete paraplegic. Once the oxygen sensor equilibrated, a 5-minute baseline reading was taken. Electrical stimulation was applied with the active (ie negative) electrode at spinal level T6 and the dispersive electrode at L2. $\mathrm{P}_{\mathrm{tc}} \mathrm{O}_{2}$ was recorded at 5-minute intervals during 60 minutes of stimulation, followed by a 20 -minute observation period. This procedure was performed twice on each subject a few days apart. Parameters were first set at 50 volts and $10 \mathrm{~Hz}$, and then at 75 volts and $10 \mathrm{~Hz}$.

In experiment 2, 29 SCI subjects were administered HVPGS while lying supine. The active electrode was placed at spinal level T6 and the dispersive electrode at T12. The subject was turned on his back and the oxygen sensor allowed to equilibrate. Within a few minutes of being activated, the displayed $\mathrm{P}_{\mathrm{tc}} \mathrm{O}_{2}$ value decreased substantially and slowly approached a stable level as the sacral area was warmed and local arterialization occurred. Twenty minutes were allowed for the sensor to stabilize. The monitor was considered equilibrated if, at the end of this time, $\mathrm{P}_{\mathrm{tc}} \mathrm{O}_{2}$ remained constant over a 4-minute interval. $\mathrm{P}_{\mathrm{tc}} \mathrm{O}_{2}$ values were recorded at 2-minute intervals and the reading at 10 minutes was defined as the baseline value. The electrical stimulator was activated and $\mathrm{P}_{\mathrm{tc}} \mathrm{O}_{2}$ levels were recorded at 2-minute intervals for 30 minutes. The stimulator was then switched off and $\mathrm{P}_{\mathrm{tc}} \mathrm{O}_{2}$ readings were taken for a further 15 minutes. Subjects were carefully monitored during the experiment to ensure that the oxygen tension sensor was securely attached and functioning correctly. Statistical comparisons were made between the baseline $\mathrm{P}_{\mathrm{tc}} \mathrm{O}_{2}$ measurement and the $\mathrm{P}_{\mathrm{tc}} \mathrm{O}_{2}$ reading taken (a) after 30 minutes of HVPGS, and (b) at the end of the 15 minute poststimulation period. Data were collected for each subject on: level of SCI, days since SCI, reported weight at the time of injury, smoking habits in the past month, blood pressure and pulse, as well as the site, number and grade of existing pressure ulcers. ${ }^{46}$

Experiment 3 was carried out on 5 subjects, all of whom had previously participated in experiment 2 , to determine the effect of simulated HVPGS on sacral $\mathrm{P}_{\mathrm{tc}} \mathrm{O}_{2}$ levels in subjects lying supine. The objective was to control for the effect of electrical stimulation as well as the possible placebo effect of the stimulator. The same procedures were used as in experiment 2: the stimulator electrodes were taped to the subject and $\mathrm{P}_{\mathrm{tc}} \mathrm{O}_{2}$ levels were monitored for the same time intervals, but the stimulator was not activated.

In experiment 4 , the procedures of experiment 2 was repeated on 10 subjects to determine the reproducibility of HVPGS. Comparisons were made between (a) the two baseline values, (b) the two $\mathrm{P}_{\mathrm{tc}} \mathrm{O}_{2}$ levels attained with HVPGS, and (c) percentage increases in $\mathrm{P}_{\mathrm{tc}} \mathrm{O}_{2}$ levels following HVPGS.

The data were analyzed using repeated measures analysis of variance, followed by Newman-Keuls post-hoc tests to determine specific within- and between-group differences. $^{47}$ 


\section{Results}

\section{Experiment 1}

HVPGS applied to the 3 SCI subjects lying prone led to a sustained, dose-related increase in $\mathrm{P}_{\mathrm{tc}} \mathrm{O}_{2}$ at the sacrum, the increase being more dramatic in the 2 subjects with baseline $\mathrm{P}_{\mathrm{tc}} \mathrm{O}_{2}$ values at or below the lower end of the normal range of $60-100 \mathrm{mmHg}$ (Figure 1 represents subject 1). All three subjects exhibited increases in $\mathrm{P}_{\mathrm{tc}} \mathrm{O}_{2}$ when HVPGS was increased from 50 volts to 75 volts. The largest increase in $\mathrm{P}_{\mathrm{tc}} \mathrm{O}_{2}$ observed in any subject (at 75 volts) was $57 \%$ above baseline (Fig 1); moreover, in 2 of the 3 subjects there was no indication that $\mathrm{P}_{\mathrm{tc}} \mathrm{O}_{2}$ had increased to the maximal extent during stimulation. For the 3 subjects, neither set of parameters ( 50 volts or 75 volts) caused a visible contraction of the back muscles, and none reported any type of discomfort with the procedure. One subject described a warming sensation in his back during HVPGS. It should be noted that stimulation at 100 volts was found to have no additional incremental effect on $\mathrm{P}_{\mathrm{tc}} \mathrm{O}_{2}$ levels above that achieved with 75 volts. Hence, subsequent experiments were performed using 75 volts.

\section{Experiment 2}

Twenty-nine SCI persons (26 males and 3 females) undergoing rehabilitation were recruited for the study after obtaining their written informed consent. The characteristics of the $29 \mathrm{SCI}$ persons are shown in Table I.

The stimulator electrodes and $\mathrm{P}_{\mathrm{tc}} \mathrm{O}_{2}$ sensor were positioned as described above. Electrical stimulation $(75$ volts, $10 \mathrm{~Hz})$ was administered for 30 minutes while subjects lay supine, after a 15-minute baseline period. This was followed by an observation period of 15 minutes (Fig 2). Compared to the final baseline $\mathrm{P}_{\mathrm{tc}} \mathrm{O}_{2}$ reading (Mean \pm SD) of $49 \pm 21 \mathrm{mmHg}$, the level attained at the end of the 30 -minute period of HVPGS was $66 \pm 18 \mathrm{mmHg}-35 \%$ higher, a highly significant increase $(F=39.42$,

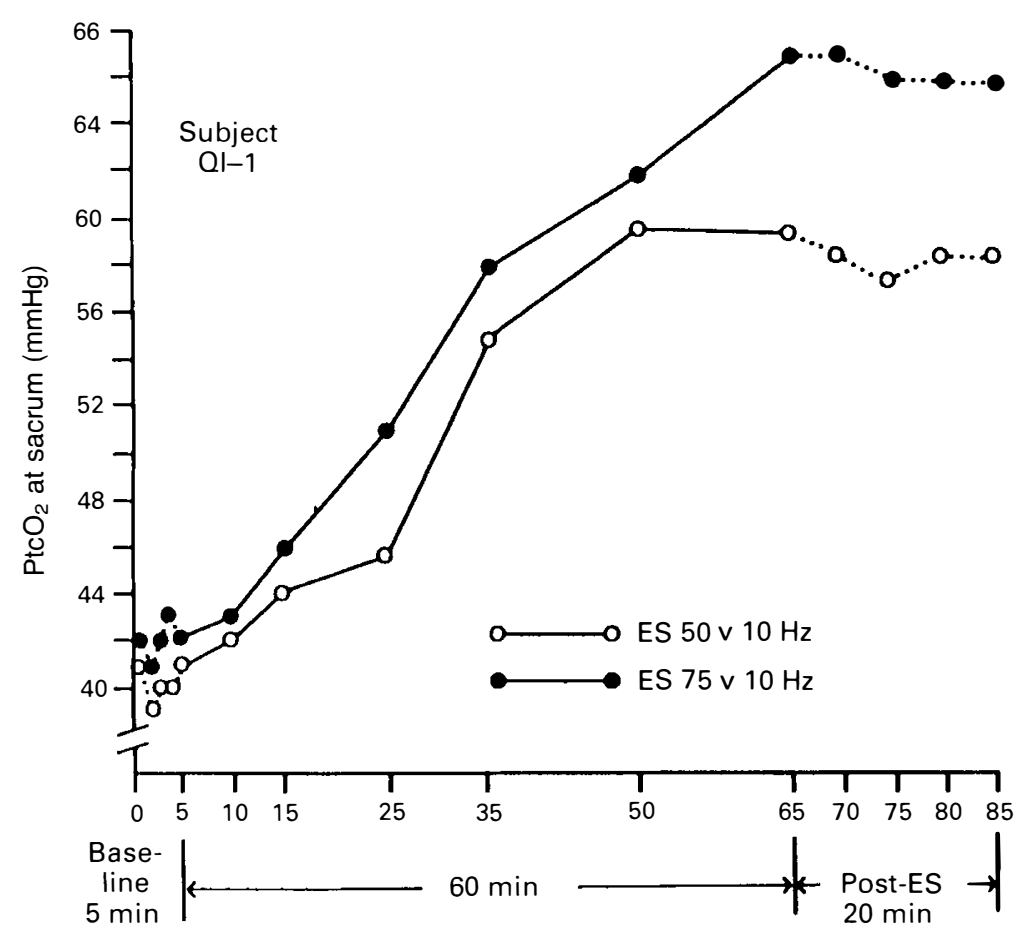

Figure 1 Sacral $\mathrm{PtcO}_{2}$ response to high voltage pulsed galvanic stimulation at different voltages at spinal levels $\mathrm{T} 6-\mathrm{L} 2$ in subject with incomplete quadriplegia $(\mathrm{QI}-1)$. 
Table 1 Characteristics of the 29 spinal cord injured patients participating in the study

\begin{tabular}{|c|c|c|}
\hline Characteristic & $N$ & $\%$ \\
\hline \multicolumn{3}{|l|}{ Race } \\
\hline White & 7 & 24 \\
\hline Black & 22 & 76 \\
\hline \multicolumn{3}{|l|}{ Gender } \\
\hline Male & 26 & 90 \\
\hline Female & 3 & 10 \\
\hline \multicolumn{3}{|l|}{ Days since SCI } \\
\hline Mean 87 days, SD 95 days & & \\
\hline Cigarette smokers $(1+$ packs/day) & 27 & 93 \\
\hline \multicolumn{3}{|l|}{ Age at SCI } \\
\hline \multicolumn{3}{|l|}{ Reported weight at SCI } \\
\hline $\begin{array}{l}\text { Systolic blood pressure } \\
\text { Mean } 110 \mathrm{mmHg}, \mathrm{SD} 12 \mathrm{mmHg}\end{array}$ & & \\
\hline $\begin{array}{l}\text { Diastolic blood pressure } \\
\quad \text { Mean } 68 \mathrm{mmHg}, \mathrm{SD} 11 \mathrm{mmHg}\end{array}$ & & \\
\hline $\begin{array}{l}\text { Pulse rate } \\
\text { Mean } 78 \text { beats/min, SD } 17 \text { beats/1 }\end{array}$ & & \\
\hline \multicolumn{3}{|l|}{ Diagnosis } \\
\hline Complete quadriplegia & 5 & 18 \\
\hline Incomplete quadriplegia & 4 & 14 \\
\hline Complete paraplegia & 11 & 39 \\
\hline Incomplete paraplegia & 7 & 25 \\
\hline Uncertain & 1 & 4 \\
\hline \multicolumn{3}{|l|}{ Level of lesion } \\
\hline $\mathrm{C} 1-\mathrm{C} 3$ & 1 & 3 \\
\hline $\mathrm{C} 4$ & 2 & \\
\hline $\mathrm{C} 5$ & 1 & 3 \\
\hline C6 & 5 & 17 \\
\hline $\mathrm{C} 7-8$ & 3 & 10 \\
\hline $\mathrm{T} 1-5$ & 7 & 24 \\
\hline T6-12 & 8 & 28 \\
\hline $\mathrm{L} 1-\mathrm{S} 5$ & 2 & \\
\hline \multicolumn{3}{|l|}{ Causes of SCI } \\
\hline Gunshot wound & 16 & 55 \\
\hline Stab & 2 & 7 \\
\hline Motor vehicle accident & 7 & 24 \\
\hline Diving & 1 & 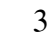 \\
\hline Fall & 3 & 10 \\
\hline \multicolumn{3}{|l|}{ Pressure ulcers } \\
\hline One or more & 10 & 34 \\
\hline \multicolumn{3}{|l|}{ Site of pressure ulcer } \\
\hline Sacral & 7 & 70 \\
\hline Heel & 2 & 20 \\
\hline Other & 1 & 10 \\
\hline \multicolumn{3}{|l|}{ Grade of only or largest pressure ulcer } \\
\hline Grade 1 & 1 & 10 \\
\hline Grade 2 & 2 & 20 \\
\hline Grade 3 & 4 & 40 \\
\hline Grade 4 & 3 & 30 \\
\hline
\end{tabular}

$p<0.00001)$. This level fell only slightly to $63 \pm 21 \mathrm{mmHg}$ by the end of the 15 -minute poststimulation period, still significantly above baseline $(F=39.42, p<0.00001)$.

\section{Experiment 3}

The same procedure as in experiment 2 was repeated on 5 subjects, including the attachment of the sensor and HVPGS electrodes, but the stimulator was not activated. The results of simulated HVPGS on $\mathrm{P}_{\mathrm{tc}} \mathrm{O}_{2}$ levels are also depicted in Figure 2. It can be seen that no change occurred in mean $\mathrm{P}_{\mathrm{tc}} \mathrm{O}_{2}$ levels throughout the course of the experiment.

\section{Experiment 4}

Ten subjects were administered HVPGS on two separate occasions, in most instances within a few days of each other, to determine the reproducibility of the effects. The results were highly consistent; thus, when mean baseline $\mathrm{P}_{\mathrm{tc}} \mathrm{O}_{2}$ levels, $\mathrm{P}_{\mathrm{tc}} \mathrm{O}_{2}$ levels attained with HVPGS, and percentage increases in $\mathrm{P}_{\mathrm{tc}} \mathrm{O}_{2}$ from baseline were compared with each other, no significant differences were observed $(F=0.21$, $p=0.66$, in all comparisons).

\section{Discussion}

In previous research, ${ }^{15}$ we compared sacral $\mathrm{P}_{\mathrm{tc}} \mathrm{O}_{2}$ levels in $21 \mathrm{SCI}$ persons and 11 able bodied controls lying prone and supine. In the prone position, that of the controls (Mean \pm SD) was $76 \pm 13 \mathrm{mmHg}$ compared to $65 \pm 16 \mathrm{mmHg}$ in the SCIs $(p=0.053)$. In the supine position, however, while the $\mathrm{P}_{\mathrm{tc}} \mathrm{O}_{2}$ level of the controls remained virtually unchanged at $74 \pm 10 \mathrm{mmHg}$, that of the SCI persons quickly dropped to $49 \pm 26 \mathrm{mmHg}$. Using these supine levels for able bodied controls as the standard for normality, the results obtained in the present experiments support the hypothesis that HVPGS can reliably increase the sacral $\mathrm{P}_{\mathrm{tc}} \mathrm{O}_{2}$ levels of SCI persons lying supine into the normal range. A dose-related increase in sacral $\mathrm{P}_{\mathrm{tc}} \mathrm{O}_{2}$ levels was also observed (100 volts $<75$ volts $>50$ volts) in $3 \mathrm{SCI}$ persons lying prone (experiment 1 ).

Since ischemic injury at the sacrum occurs 


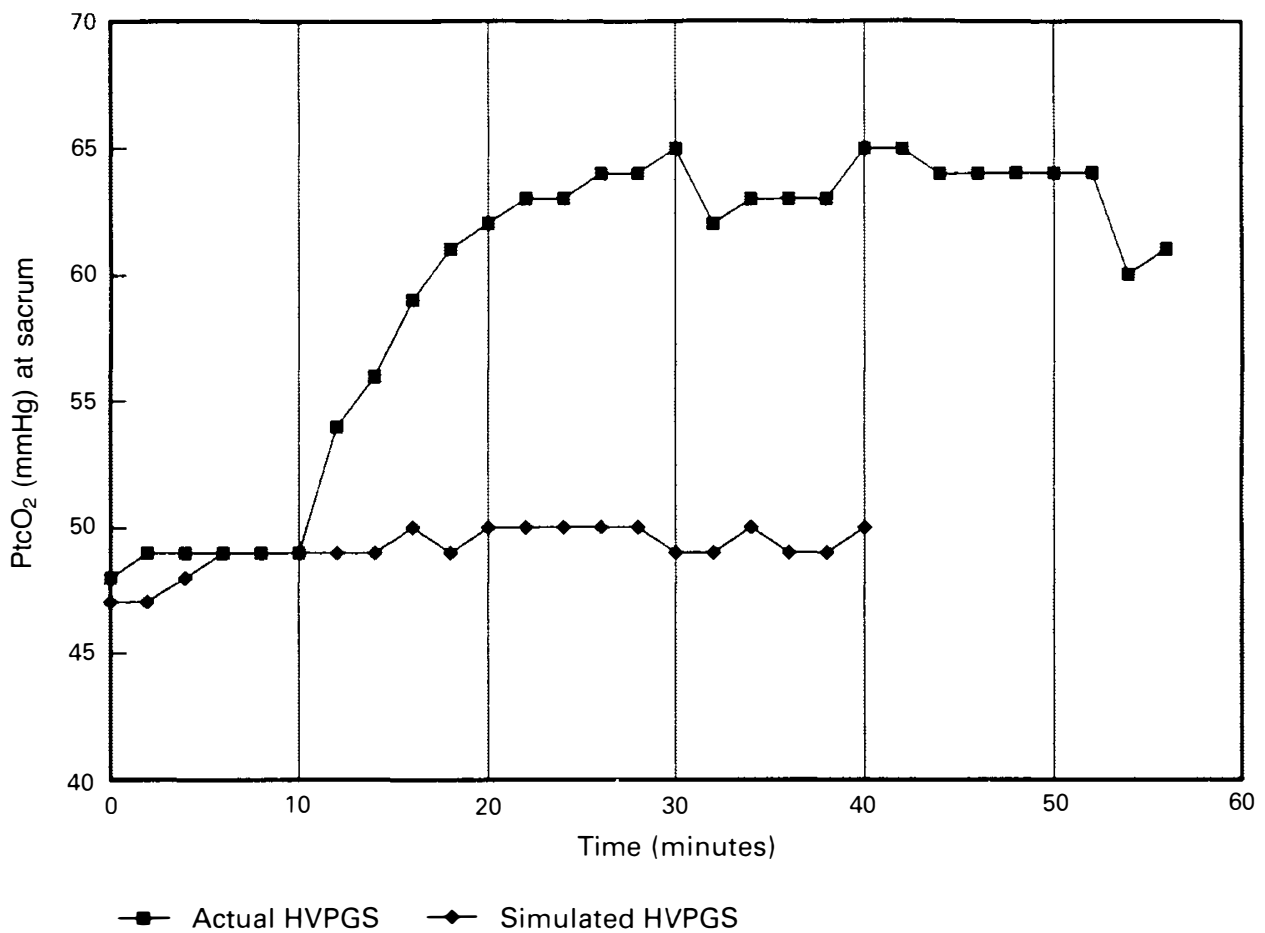

Figure 2 Effect of high voltage pulsed galvanic stimulation (HVPGS: 75 volts, $10 \mathrm{~Hz}$ ) on sacral transcutaneous oxygen tension levels in spinal cord injured subjects lying supine. Actual HVPGS ( $n=29$; baseline, $0-10 \mathrm{~min}$; stimulation period, 10-40 min; poststimulation period, $40+\mathrm{min}$ ). Simulated HVPGS ( $n=5$; baseline. $0-10 \mathrm{~min}$; simulation period, $10-40 \mathrm{~min}$ ).

in the supine position, the paramount issue is whether HVPGS can produce clinically significant increases in $\mathrm{P}_{\mathrm{tc}} \mathrm{O}_{2}$ in this position. Experiment 2 showed that sacral $\mathrm{P}_{\mathrm{tc}} \mathrm{O}_{2}$ levels of SCI persons lying supine could indeed be increased $35 \%$ from the baseline level of $49 \pm 21 \mathrm{mmHg}$ to $66 \pm 18 \mathrm{mmHg}$, and hence into the normal range. To counter the charge that this effect could have occurred by chance or as a result of the placebo effect, experiment 3 was carried out to determine the effect of simulated HVPGS. As expected, $\mathrm{P}_{\mathrm{tc}} \mathrm{O}_{2}$ levels remained virtually unchanged throughout the experiment, supporting the hypothesis that HVPGS can increase $\mathrm{P}_{\mathrm{tc}} \mathrm{O}_{2}$ in SCI subjects lying prone or supine. A further study (experiment 4) carried out on 10 subjects, showed that the effects of HVPGS were highly reproducible.

It remains to be determined whether HVPGS can increase and normalize $\mathrm{P}_{\mathrm{tc}} \mathrm{O}_{2}$ levels in SCI persons over prolonged periods, as would be necessary to prevent pressure ulcers, and whether prolonged stimulation has adverse effects. No instance of burning or skin irritation was reported or observed in our experiments. An interesting observation in our study was that $\mathrm{P}_{\mathrm{tc}} \mathrm{O}_{2}$ levels tended to remain high and significantly above baseline for the duration of the 15 minute poststimulatory period, suggesting that intermittent HVPGS could be used in long term clinical applications. This would serve to minimize the risk of adverse effects on the skin.

Spinal cord injury results in autonomic dysfunction involving varying degrees of sympathetic loss with unopposed parasympathetic activity. ${ }^{48}$ Since the systemic vascular resistance is mainly a function of the sympathetic nervous system (SNS), the former drops to extremely low levels following SCI, especially cervical cord injury. 
Systolic pressures in the range of $90 \mathrm{mmHg}$ are common, with mean diastolic pressures of about $60-70 \mathrm{mmHg}$, reflecting a massive decrease in systemic vascular resistance and generalized vasodilatation. ${ }^{48}$ Quadriplegic persons also have significantly lower basal plasma norepinephrine and epinephrine levels than neurologically intact controls. ${ }^{49,50}$ The mechanism by which HVPGS increases sacral $\mathrm{P}_{\mathrm{tc}} \mathrm{O}_{2}$ levels in SCI awaits investigation. One possibility is that HVPGS activates the peripheral SNS below the level of the spinal cord lesion, thereby increasing the perfusion pressure gradient in the capillary beds and enhancing tissue oxygenation.

In conclusion, HVPGS can reliably increase the typically low sacral $\mathrm{P}_{\mathrm{tc}} \mathrm{O}_{2}$ levels of SCI persons into the normal range. Randomized controlled trials are now indicated to determine the efficacy of HVPGS for preventing pressure ulcers in SCI persons and other high risk groups. Considering that pressure ulcers can develop immediately following acute SCI, ${ }^{2.4 .5}$ an appropriate starting point would be a trial of HVPGS during this critical, early postinjury period.

\section{Acknowledgements}

Thanks are due to Novametrix Medical Systems, Wallingford, CT, and Medical Devices Inc, St Paul, MN, for lending the equipment used in this study; to the nursing staff of the Louisiana Rehabilitation Institute, New Orleans, for their cooperation; and to Lisanne Brown, Jeffrey Williams and Richard Chambers for assisting with the statistical analysis.

\section{References}

1 Kosiak M, Kottke F (1990) The prevention and rehabilitation of ischemic ulcers. In: F Kottke, J Lehmann, editors. Krusen's Handbook of Physical Medicine and Rehabilitation. Chapter 46. 4th ed. W B Saunders, Philadelphia: 976-987.

2 Richardson RR, Meyer PR (1981) Prevalence and incidence of pressure sores in acute spinal cord injury. Paraplegia 19: 235-247.

3 Anderson KE, Jenson O, Kvorning SA, Bach E (1982) Prevention of pressure sores by identifying patients at risk. $B r$ Med J 284: 1370-1371.

4 Mawson AR, Biundo JJ Jr., Neville P, Linares H, Lopez A (1988) Risk factors for early-occurring pressure ulcers following spinal cord injury. Am J Phys Med Rehabil 67: 123-127.

5 Bliss MR (1992) Aute pressure area care: Sir James Paget's legacy. Lancet 339: 221-223.

6 Kosiak M (1959) Etiology and pathology of ischemic ulcers. Arch Phys Med Rehabil 40: 62-68.

7 Dinsdale SM (1974) Decubitus ulcers: role of pressure and friction in causation. Arch Phys Med Rehabil 55: 147-152.

8 Reuler JB, Cooney TG (1981) The pressure sore: Pathophysiology and principles of management. Ann Intern Med 94: 661-666.

9 Perdue KW, Wilson JL (1989) Decubitus ulcers. J Am Board Fam Pract 2: 43-48.

10 Guttmann L (1976) Spinal Cord Injuries: Comprehensive Management and Research. 2nd ed. Blackwell, Oxford.

11 Hunt TK, Conolly WB, Aronson SB, Goldstein P (1978) Anaerobic metabolism and wound healing: hypothesis for initiation and cessation of collagen synthesis in wounds. Am J Surg 135: 328-332.

12 Rodriguez GP, Claus-Walker J, Kent MC, Stal S (1986) Adrenergic receptors in insensitive skin of spinal cord injured patients. Arch Phys Med Rehabil 67: 177-180.

13 Bennett L, Kavner D, Lee BY, Trainor FR, Lewis JM (1984) Skin stress and blood flow in sitting paraplegic patients. Arch Phys Med Rehabil 65: 186-190.

14 Schubert V, Fagrell B (1991) Postocclusive reactive hyperemia and thermal response in the skin microcirculation of subjects with spinal cord injury. Scand J Rehabil Med 23: 33-40.

15 Mawson AR, Siddiqui FH, Connolly B, Sharp CJ, Summer WR, Biundo JJ Jr (in press) Sacral transcutaneous oxygen tension levels in the spinal cord injured: risk factor for pressure ulcers? Arch Phys Med Rehabil.

16 Bogie KM, Nuseibeh I, Bader DL (1992) Transcutaneous gas tensions in the sacrum during the acute phase of spinal cord injury. Proceedings of the Institute of Mechanical Engineers, Part H. J Engr Med 206: 1-6.

17 Bliss MB, McLaren R, Exton-Smith AN (1967) Preventing pressure sores in hospital: controlled trial of a large-celled ripple mattress. $\mathrm{Br}$ Med J 1: 394-397.

18 Exton-Smith AN, Overstall PW, Wedgwood J, Wallace G (1982) Use of the 'air-wave' system to prevent pressure sores in hospital. Lancet 1: 1288-1290.

19 Editorial (1990) Preventing pressure sores. Lancet 335: 1311-1312.

20 Young JB (1990) Aids to prevent pressure sores. Br Med J 300: 1002-1004. 
21 Young J, Cotter D (1990) Pressure sores: do mattresses work? Lancet 336: 182-183.

22 Tallis RC, Illis LS, Sedgwick EM, Hardwidge C, Kennedy K (1982) The effects of spinal cord stimulation upon peripheral blood flow in patients with chronic neurological disease. Int Rehabil Med 5: 4-9.

23 Kaada B (1983) Promoted healing of chronic ulceration by transcutaneous nerve stimulation (TNS). VASA 12(3): 262-9.

24 Katz RT, Green D, Sullivan T, Yarkony G (1986) Functional electrical stimulation for deep venous thrombosis in the spinal cord injured patient. Arch Phys Med Rehabil 67: 629 (abstract).

25 Levine SP, Kett RL, Gross MD, Wilson BA, Cederna PS, Juni JE (1990) Blood flow in the gluteus maximus of seated individuals during electrical muscle stimulation. Arch Phys Med Rehabil 71: 682-686.

26 Young GH (1966) Electrical impulse therapy aids wound healing. Mod Vet Pract 47: 60-62.

27 Cook AW, Oygar A, Baggenstos P, Pacheco S, Kleriga E (1976) Vascular disease of the extremities: electrical stimulation of the spinal cord and the posterior roots. NY State J Med 76: 36-38.

28 Chalker M (1983) Healing of decubitus ulcers in patients in neurokinesthetic program with the electroacuscope 80. Crit Care Update March: 50-52.

29 Akers TK, Gabrielson AL (1984) The effect of high voltage galvanic stimulation on the rate of healing of decubitus ulcers. Biomed Sci Instrum 20: 99-100.

30 Barron JJ, Jacobsen WE, Tidd G (1985) Treatment of decubitus ulcers: A new approach. Minn Med 8: 103-106.

31 Carley PJ, Wainapel SF (1985) Electrotherapy for acceleration of wound healing: low intensity direct current. Arch Phys Med Rehabil 66: 443-446.

32 Newton RA (1987) High voltage pulsed galvanic stimulation: theoretical bases and clinical applications. In: R M Nelson, D P Currier, editors. Clinical Electrotherapy. Appleton \& Lange, Norwalk, Connecticut: 166-182.

33 Weiss DS, Kirsner R, Eaglestein WH (1990) Electrical stimulation and wound healing. Arch Dermatol 126: $222-225$.

34 Alon G, Alaria M, Stein H (1986) Diabetic ulcer healing using high voltage TENS. Phys Ther 66: 775.

35 Brown M, Gogia P (1986) Effects of high voltage galvanic stimulation on wound healing. Phys Ther 66: 748.

36 Feedar JA, Kloth LC (1985) Acceleration of wound healing with high voltage pulsed direct current. Phys Ther 65: 741.

37 Kloth LC, Feedar JA (1988) Acceleration of wound healing with high voltage, monophasic, pulsed current. J Am Phys Ther Assoc 68: 503-508.

38 Unger P (1985) Wound healing with high voltage galvanic stimulation. Stimulus 10: 3-6.

39 Bourguignon GJ, Bourguignon LYW (1987) Electric stimulation of protein and DNA synthesis in human fibroblasts. FASEB J 1: 398-402.

40 Dodd HJ, Gaylarde PM, Sakany I (1985) Skin oxygen monitoring in newborn. J R Soc Med 78: 373-376.

41 Tooley WH (1980) A comparison of transcutaneous and arterial $\mathrm{PO}_{2}$ values in infants using the Air-Shields $\mathrm{TcPO}_{2}$ monitoring system. Air-Shields, Hatboro, Pennsylvania.

42 Hader CF, Sorenson ER (1988) The effects of body position on transcutaneous oxygen tension. Pediatr Nursing 14(6): 469-473.

43 Tremper KK, Shoemaker WC (1981) Transcutaneous oxygen monitoring of critically ill adults with and without low flow shock. Crit Care Med 9: 706-709.

44 Newton RA, Karselis TC (1983) Skin pH following high voltage pulsed galvanic stimulation. Phys Ther 63: 1593-1595.

45 Procacci P, Della Corte M, Zoppi M, Romano S, Maresca M, Voegelin MR (1974) Pain threshold measurements in man. In: J J Bonica, editor. Recent Advances in Pain, Pathophysiology and Clinical Aspects. Thomas Springfield, Illinois: 105-147.

46 Enis JE, Sarmiento A (1973) The pathophysiology and management of pressure sores. Orthop Rev 2: $25-34$.

47 BMDP Statistical Software, Inc (1990) BMDP Manual. University of California Press, Berkeley, California.

48 Rosner MJ, Elias Z, Coley I (1984) New principles of resuscitation for brain and spinal injury. N Carolina Med J 45: 701-6.

49 Munro A. Robinson R (1960) Catecholaminergic content of peripheral plasma in human subjects with complete transverse lesions of the spinal cord. J Physiol 154: 244-253.

50 Mathias CJ, Christensen NJ, Corbett JL, Frankel HL, Spalding JMK (1976) Plasma catecholamines during paroxysmal neurogenic hypertension in quadriplegic man. Circ Res 39: 204-208. 